\title{
TERMINOLOGIZATION AND DEFINITION OF PROJECT-BASED LEARNING
}

\author{
Aidyn Aldaberdikyzy ${ }^{1}$, Nurgissa Berdibay ${ }^{2}$ \\ ${ }^{1}$ L. N. Gumilyov Eurasian National University \\ ${ }^{2}$ Korkyt ata Kyzylorda university \\ ORCID ID iD: 0000-0002-2991-5867 \\ ORCID ID ${ }^{\text {DD }: 0000-0002-4885-5150 ~}$
}

\begin{abstract}
New, convenient, compact, understandable and effective approaches are needed for all students to master their language learning. Considering these criteria, we can consider one of the young approaches that are currently developing. It is a Project-based learning approach. Project-based learning is the abbreviation of $P B L$, which will use throughout article. The article provides a brief overview of the theoretical approaches to project-based learning.

This approach is one of the most useful and absorbing methods in teaching and it was created as an idea in the twentieth century; today it is one of the beneficial approaches in education. The use of project-based learning in the classroom really comes in handy for those situations where students are just bored at lectures. The best part of PBL is that it increases student engagement. Student will enjoy working on these projects and be much more pleasant.

This article explains theoretical fundamentals of PBL and the benefits of project-based learning technology.
\end{abstract}

\section{INTRODUCTION}

In connection with the socio-economic changes in the world in modern society, there is a need for active people who can quickly adapt to changing working conditions, perform work with optimal energy consumption, and are capable of self-education, self-education, and self-development..

Among the most important qualities of a modern person are active mental activity, critical thinking, the search for new things, the desire and ability to acquire knowledge independently. Thus, education is assigned a function that would contribute to the development of independence and responsibility of the individual, would be focused on its self-development, self-education, selfrealization [Erusalimov et al, 2021].

Therefore, as teachers rightly note, it is necessary to change the existing didactic paradigm, focused on traditional reproductive education, by changing the forms and methods of teaching, its individualization, increasing the complex of the latest technical means, and the widespread use of new teaching technologies. Moreover, the emphasis is placed on more active types of independent individual work.

Independent work contributes to the development of skills and abilities related to the organization of their own work. This includes planning your activities, realistic perception of your capabilities, and the ability to work with information, which is especially important in connection with the intensive growth of the volume of scientific and technical information and the rapid updating of knowledge [Dewey, John., 1909].

Project-based learning is often abbreviated to the acronym PBL. So, what is Project-based learning? Project-based learning (PBL) is a student-centered pedagogical method in which students acquire by engaging in real-world absorbing and personally meaningful projects. Students learn about a certain subject by participating in projects. Students acquire by working for a lengthened period to investigate and respond to a complex question, challenge, or problem.

The project method originated at the beginning of the last century in the United States. It was also called the method of problems, and it was associated with the ideas of the humanistic direction 
in philosophy and education, this method is based on the ideas of the American philosopher and educator John Dewey, and his colleague and a successor William H. Kilpatrick, and other American scientists. The design method appeared in 1919 in America. Dewey states, "When we experience something, we act upon it, we do something with it; then we suffer or undergo the consequences. We do something to the thing and then it does something to us in return". The result of this trying and undergoing is learning - learning from experience [Bob Lenz., 2018]. Then Kilpatrick took this idea and made it more concretely accessible the developing techniques of project method. Kilpatrick generalized project method as a "wholehearted purposeful activity proceeding in a social environment (Kilpatrick, William Heard "The project method") [Boss, 2015].

Nowadays PBL is developing among CIS (Commonwealth of independent states) countries. At first PBL was researched as a theory with Russian scientists V.P.Bespalko, V.V. Davydov, V.K. Dyachenko, L.V.Zankov, P.Ya.Galperin and N.V.Kuzmina as well as E.N.Ilyin, S. N.Lysenkova their experiences focused on the practical way and are considered in Kazakh scientists in the works of Sh.Taubayeva, U.B.Zheksenbayeva, Z.A.Issayeva, and S.Izmuhambetova developed the PBL with their complete works.

The main purpose of using PBL is to develop students' interest, improve knowledge through independent work, develop information orientation skills and increase the ability to think critically, adapt students to self-realization in the future in various situations, in various social environments. [Fleming, D. S., 2002].

The main tasks and process of PBL are preparation; planning the process; setting goals; research; conclusions; presentation and Evaluation.

According to Papandreou (1994) [Papandreou, A. P., 1993] in "An Application of the Projects Approach to EFL" introduces a model which illustrates the process of project work in six steps:

Step 1 Preparation: The teacher explains the topic to the pupils and invites them to discuss and ask questions during this period.

Step 2 Planning: in this period, the teacher explains the topic to the pupils and invites them to discuss and ask questions.

Step 3 Research: in this part, Students work individually or in groups to collect information from various sources.

Step 4 Conclusions: Based on their analysis of the collected data, the students reach conclusions.

Step 5 Presentation: the students are present their final product to the whole class.

Step 6 Evaluation: In this section, the teacher comments on the students' efforts and endeavors.

Each class project should start with a driving question that is specifically related to the learning goal. Driving questions are questions that cannot be replied with a simple "yes or no" answers, these are also called provocative or open-ended questions. The difficulty level of the driving question should be appropriate for the type of student in the class. What is the main question? The driving question identifies the purpose of project-based learning for students and teachers. It sets the context for project-based learning and refers to content standards. The driving question should be clear, provocative, open, challenging and related to the essence of what teachers want students to learn. Without the driving question, students may not understand why they are taking on a project; in addition, strong driving questions give students insight and appreciation for the planned exploration and action during the project [Larmer, Mergendoller \& Boss, 2015]. For example: How do we design a pet shop? The next step for implementation is the inquiry process. Students should apply learned knowledge ask and answer critical thinking questions and locate resources. In the next step students find a solution to the given topic. Here is where students solve the problems often time with creations, models and presentations. And the last step is to allow students to make their projects available to the public [Carter, C., 2000].

Demonstration of learning through performances or products. Students represent their learning through multimedia presentations, print materials, performances, models, simulations, or other means (e.g., videotapes, brochures, plays or skits, recitals, musical scores, computer assisted 
presentations).The audience for these performances or products may include other students, parents, and community members.

\section{CONCLUSION}

The use of PBL activates thinking processes (memory, thinking, imagination, attention), promotes better assimilation of the studied material, and helps students to see the practical orientation of learning a foreign language. When evaluating students' projects, it would be more correct to pay more attention to the content (quality of the material, organization, design, useful links $-70 \%$ ), rather than to the form (site composition, language, authorship -30\%). It is important to consider the ability to correctly express your thoughts in a foreign language, the selection of material, its structuring, the ability to make comparisons and conclusions [Sergeev, 2008].

The work on the project should not be directly evaluated by the teacher with the help of points. From experience, we note that a combined assessment is appropriate, which consists of an assessment of external observers, guests, a presentation, as well as a self-assessment of the team of project authors in the form of an analytical note, a schedule, a speech, etc. PBL is important for students and in education in general. Project-based learning can be used by various disciplines. Some of the important reasons for using projects in the classroom, such as allowing students to develop communication skills. Project-based learning is important for learners to gradually grow some of these $21^{\text {st }}$ century life skills. Projects are assigned as group activities being able to work with others is a necessary component of countless fields of work [Mynbayeva, Aitbaeva, Kudaibergenova, 2016].

In fact, PBL really comes in handy for those situations where students are just plain old bored of lectures. The best part of PBL is that it increases student engagement. Student will enjoy working on these projects and be much more pleasant while working. PBL is not only for students who struggle with typical classroom learning as I mentioned above, it can be used for any student because it is the most effective classroom method. Project approach can be used for many different classes. But PBL is most prevalent in social studies, science classes and art classes as well. [Sultankulova, Tulegenova, 2019]

Considering all of the above, project-based learning: Increased motivation - students "own the questions" and spend more time working on projects outside of building. Increased autonomy students become more responsible and self-directed learners. Increased achievement - students practice higher levels of thinking through direct application of factual knowledge in making interpretations, conclusions, and critical judgments.

We can say that it requires students to use specific skills, such as collaboration, teamwork, time and task management, or presentation skill, to conclude a project successfully. These skills cannot be practiced or learned through traditional transmission models of education. This approach maximizes and increases student's individual responsibility.

This technology allows each student to independently gain experience in research and practical activities expand their horizons and replenish their active and passive vocabulary. Projectbased learning technology also develops students ' various practical skills that are so necessary for them in later life, such as searching and working with information, the ability not just to express their point of view, but also to argue their answer.

\section{REFERENCES:}

Bob Lenz. (2018). Project based teaching: How to create rigorous and engaging learning experiences. Alexandria, VA: ASCD.

Boss, S. (2015). Implementing project-based learning. Bloomington, IN: Solution Tree Press. 
Carter, C. (2000). Uncommon Knowledge: Hands-on Science Projects. Charleston: Clearinghouse on Rural Education and Small Schools // Charleston, WV: ERIC Clearinghouse on Rural Education and Small Schools, 17-18p.

Dewey, John. (1909). How we think, by John Dewey . London: D.C. Heath.

Erusalimov, R., Stoykova, P., Nestorov, L., Panteleeva, I., Marinov, M. (2021). Increasing the financial literacy and economic culture of students in grades 5-10. ISBN 978-954-23-1948-1, D.A. Tsenov Academy of Economics, Svishtov

Fleming, D. S. (2002). A Teachers Guide to Project-Based Learning. // AEL, Inc., Charleston, WV, 2000 - 17p. (Retrieved June 25, 2021).

Larmer, J., Mergendoller, J. R., \& Boss, S. (2015). Setting the standard for project based learning: A proven approach to rigorous classroom instruction. 1-5 $\mathrm{p}$.

Mynbayeva, A.K. Aitbaeva, A.B. Kudaibergenova, A.M. (2016). Zhogary mektep pedagogikasy negizderi: oku kuraly [Pedagogics of higher Institution]. Almaty: Kazakh university, 207-209[in Kazakh]

Papandreou, A. P. (1993). An application of the projects approach to EFL [electronic resource]. English Teaching Forum. 32(3), p.41-42// Access mode: https://clck.ru/Y56Rz

Polat, E. S. (2003). Mietod proiektov na urokakh inostrannogo iazyka. Moskva: Academiia. (Retrieved June 01, 2021), from: https://multiurok.ru/blog/1-mietod-proiektov-na-urokakhinostrannogo-iazyka-polat-ie-s.html. [in Russian]

Reztsova, S.A. (n.d.). Telekommunikaczionnye proekty $\mathrm{v}$ obuchenii inostrannomu yazyku [Telecommunication projects in the training of foreign languages]. Moscow: Publishing Center «Ekzamen», 243[in Russian]

Sergeev, I. S. (2008). Kak orhanizovat proektnuiu deiatelnost uchashchikhsia: prakticheskoe posobie dlia rabotnikov obshcheobrazovatelnykh uchrezhdenii [How to organize the project activity of students: A practical guide for employees of general education institutions] (Moscow: Arkti). (Retrieved June 17, 2021), from https://www.twirpx.com/file/483321/ [in Russian].

Sultankulova P.U., Tulegenova A.M. (n.d.). Effectiveness of using project works at lesson. (Retrieved May 21), 2021, from https://scienceforum.ru/2019/article/2018012057. 